\title{
RESEARCH ON THE FLIGHT DYNAMICS OF OSTRINIA NUBILALIS IN MAIZE CROPS UNDER CONDITIONS OF THE CENTRAL PART OF MOLDOVA, ROMANIA
}

\author{
Paula - Lucelia Ursache ${ }^{1,2}$, Mihai Talmaciul, Elena Trotuș ${ }^{2}$, Simona - Florina Isticioaia ${ }^{2}$, \\ Georgiana - Roxana Amarghioalei ${ }^{2}$
}

${ }^{1}$ University of Agricultural Sciences and Veterinary Medicine Iasi, Romania

${ }^{2}$ Agricultural Research and Development Station Secuieni, Neamt

\author{
Corresponding address: \\ Agricultural Research and Development Station Secuieni, Neamț \\ 371 Principală Street, 617415, Secuieni, Romania \\ Tel: 0233745136 \\ E-mail: p.ursache03@gmail.com
}

http://www.doi.org/10.54574/RJPP.13.13

\begin{abstract}
Maize is one of the most cultivated plants species in Europe. Throughout Romania, maize was present on 2.68 million hectares in 2019. As such, special care should be taken to protect these crops against harmful organisms and especially insects. In the current context of the climate changes that become more visible from one year to another on agricultural crops and also on the pest attack intensity, it is necessary to know the evolution of the pest European corn borer Ostrinia nubilalis Hbn. in maize crops. For this reason, the pest was monitored under conditions of the central part of Moldavia, Romania, in order to evaluate the adult's appearance and the flight pattern. Number of adults of $O$. nubilalis collected during the study period 2018-2020 totalled 1652 specimens, of which 488 specimens were registered in 2018, 729 specimens in 2019, and 437 specimens in 2020. The flight of adults began at the end of May in 2018, respectively at the beginning of June in 2019 and 2020 and continued without interruption until the end of September each year. The flight curves of $O$. nubilalis were monitored in the study period, the maximum peaks were recorded at different times, influenced by temperature conditions and precipitation recorded in April - August. The flight of moths has undergone changes, it was interrupted by rainfall in June and July, the flight increased in intensity during August, in mid or the end of the month, when second peaks were recorded.
\end{abstract}

Key words: maize pest, Ostrinia nubilalis, flight pattern.

\section{INTRODUCTION}

Maize occupies a major place in agricultural crops structure, being one of the most cultivated plants in Europe. In Romania maize is cultivated on the largest areas, in 2019 being present on 2.68 million hectares (www.madr.ro).

There are currently some species that affect maize crops, and the list includes Diabrotica virgifera virgifera Le Conte (western corn rootworm), Ostrinia nubilalis Hbn. (European corn borer) and Helicoverpa armigera (corn earworm) (Grozea et al., 2019). European corn borer, O. nubilalis (Lepidoptera:Crambidae) is an important pest of maize crops in Romania (Trotus et al., 2018; Urechean \& Bonea, 2018; Grozea et al., 2019). The species is native to Europe, but has spread to Asia, North America and Africa. Trotuş et al. (2017) specify that the harmful entomofauna from maize crops identified in the conditions of central area of Moldavia province of Romania, belongs to the Order Coleoptera, Lepidoptera and Homoptera. There, fifteen species of pests were identified to attack maize from germination to maturity and the highest pest density was registered at the species $O$. nubilalis. The following year, a team lead by the same author, found that in this region $O$. nubilalis is an abundant species with a coefficient of variability of $20.01 \%$ and is present in all maize crops (Trotuş et al., 2018). In the central part of another Romanian region, Oltenia, the O. nubilalis 
frequency of attack in maize crops reaches an average of $22.37 \%$ (Urechean \& Bonea, 2018) and up to $40.65 \%$ (Drăghici, 2012).

Other research conducted in Romania established that the species $O$. nubilalis induced production losses in all areas where this crop is grown, in 2007 registering by region: $1.3 \%$ in Dobrogea, $8.5 \%$ in Transylvania, $10.5 \%$ in Moldavia, $11.7 \%$ in Baragan and $17.7 \%$ in the Western Plain (Popov \& Rosca, 2007, cited by Georgescu et al., 2013). In Oltenia region, $O$. nubilalis can cause serious economic damage to maize crop, depending on many factors (hybrid, climatic conditions, and technological measures) (Drăghici, 2012).

In the current context of climate change whose negative effects on crops and on the evolution and pests attack have become more visible from one year to another it is necessary to establish the evolution of the species $O$. nubilalis in maize crops. This paper presents data resulting from observations and determinations made on the occurrence and evolution of the $O$. nubilalis moth's flight during three successive years in climatic conditions from Central part of Moldavia region, Romania.

\section{MATERIALS AND METHOD}

The researches were carried out during 2018-2020 within the Plant Protection Laboratory of the Agricultural Research - Development Station Secuieni- Neamț (A.R.D.S. Secuieni), when the flight patterns of the $O$. nubilalis adults were monitored. For catching of the moths the light trap was placed in the experimental field of the A.R.D.S. Secuieni. The moth's collection was performed daily between April $1^{\text {st }}$ and September $30^{\text {th }}$ every year. The adults were collected in Petri dishes labelled with the date of collection, and subsequently confirmed at species level in the laboratory and entered in the light trap register.

The meteorological data were recorded from the VANTAGE PRO 2 weather station, located in the experimental field, the station being automated with the recording and storage of data in the computer. In interpreting the flight curve we used data on average air temperature $\left({ }^{\circ} \mathrm{C}\right)$ and the amount of precipitation $(\mathrm{mm})$.

\section{RESULTS AND DISCUSSIONS}

The climatic conditions during the flight of $O$. nubilalis are particularly important as they influence the appearance of the first adults, the duration and intensity of the flight, having an impact on the survival of the other biological stages (eggs and larvae).

Between 2018-2020, at the light trap, the number of moths collected from the species O. nubilalis sum up of 1652 moths, of which, in 2018, 488 moths were registered, 729 moths in 2019, respectively 437 moths in 2020. The flight of O. nubilalis started at the end of May in 2018, respectively at the beginning of June 2019 and 2020 and continued uninterruptedly until the end of September. Over the years, the situation was as follows:

- In 2018, the flight of the species started early, in mid-May and continued uninterruptedly until the end of September (Figure 1). The climatic conditions recorded in April and May, characterized as hot and dry, influenced the appearance and flight of moths which recorded a high intensity in the beginning of June (with 110 moths), after which it decreased in intensity, due to precipitation in the second part of June. The moth's flight during next period was not interrupted, it continued with low intensity until the end of July. The intensity of the flight increased in August, when in middle of the month there was a peak flight of 79 specimens, then from the end of August, the flight decreased in intensity and continued until the end of September. 


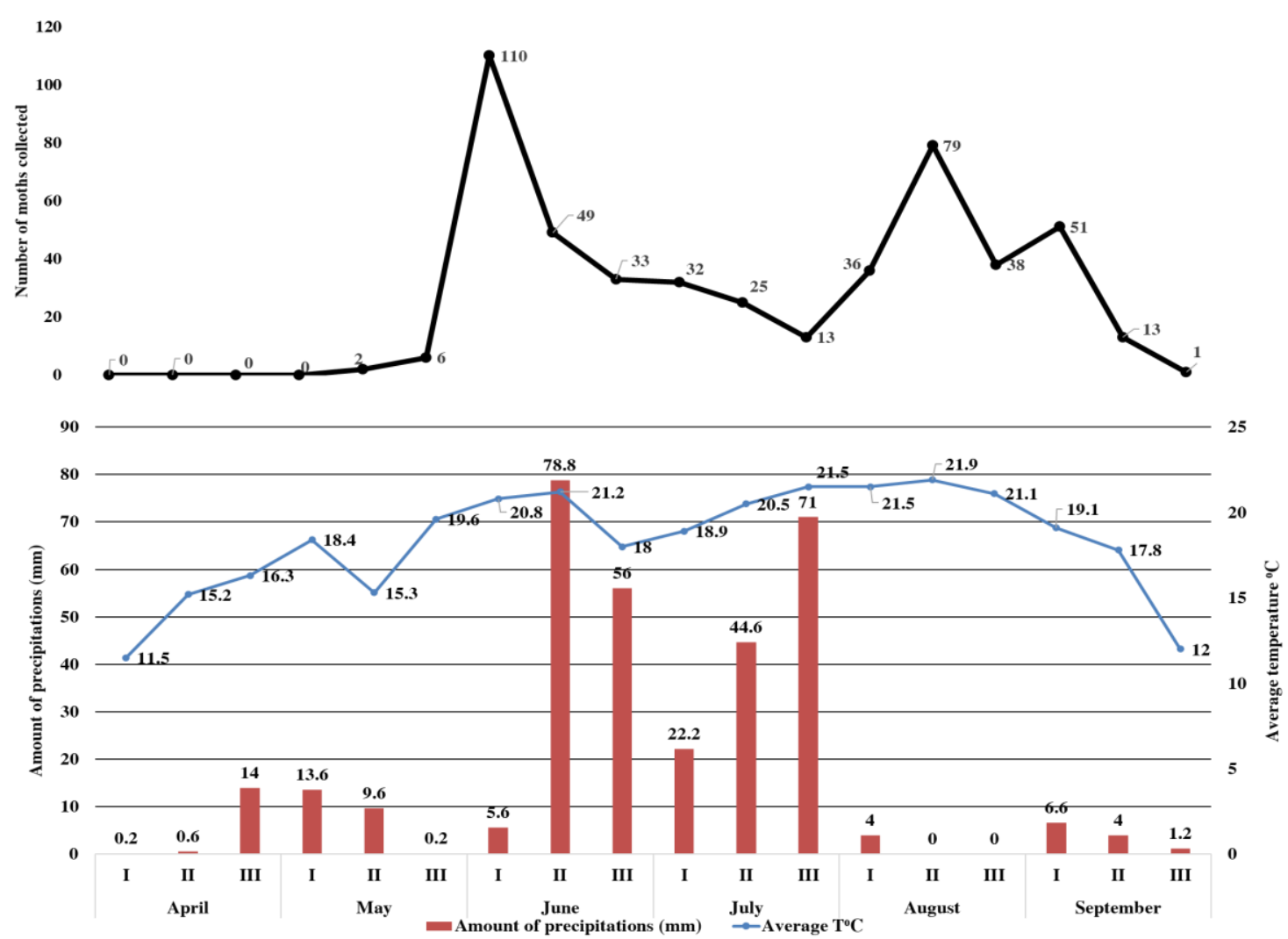

Figure 1. The Ostrinia nubilalis adults flight curve in 2018 correlated with the climate conditions from April to September

- In 2019, the $O$. nubilalis Hbn. flight started at the beginning of June and was continuous until the end of September. During this period, the species recorded a peak flight at the end of June, of 127 moths, then decreased in intensity due to precipitation recorded in July when there was a decrease in temperatures (Figure 2). In August, the flight of the species was resumed; it increased in intensity, thus registering a new peak of flight summing up to 254 moths (Figure 2).

- In 2020, the O. nubilalis Hbn. flight started in the first part of June and continued uninterrupted until the end of September. During this period, the flight peaks of the species were recorded at the end of June (97 moths), and at mid-August, when the species recorded a more intense flight, with a new maxim of 106 moths (Figure 3). The summer months of 2020 were characterized by being warmer and drier, so after the recorded peak of flight in June, the insect's flight decreased in intensity, and in August, in conditions of high temperatures, the species flight resumed, intensified and recorded a maximum flight peak at the mid- August of the month, after which the flight decreased in intensity and continued uninterrupted until midSeptember (Figure 3). 


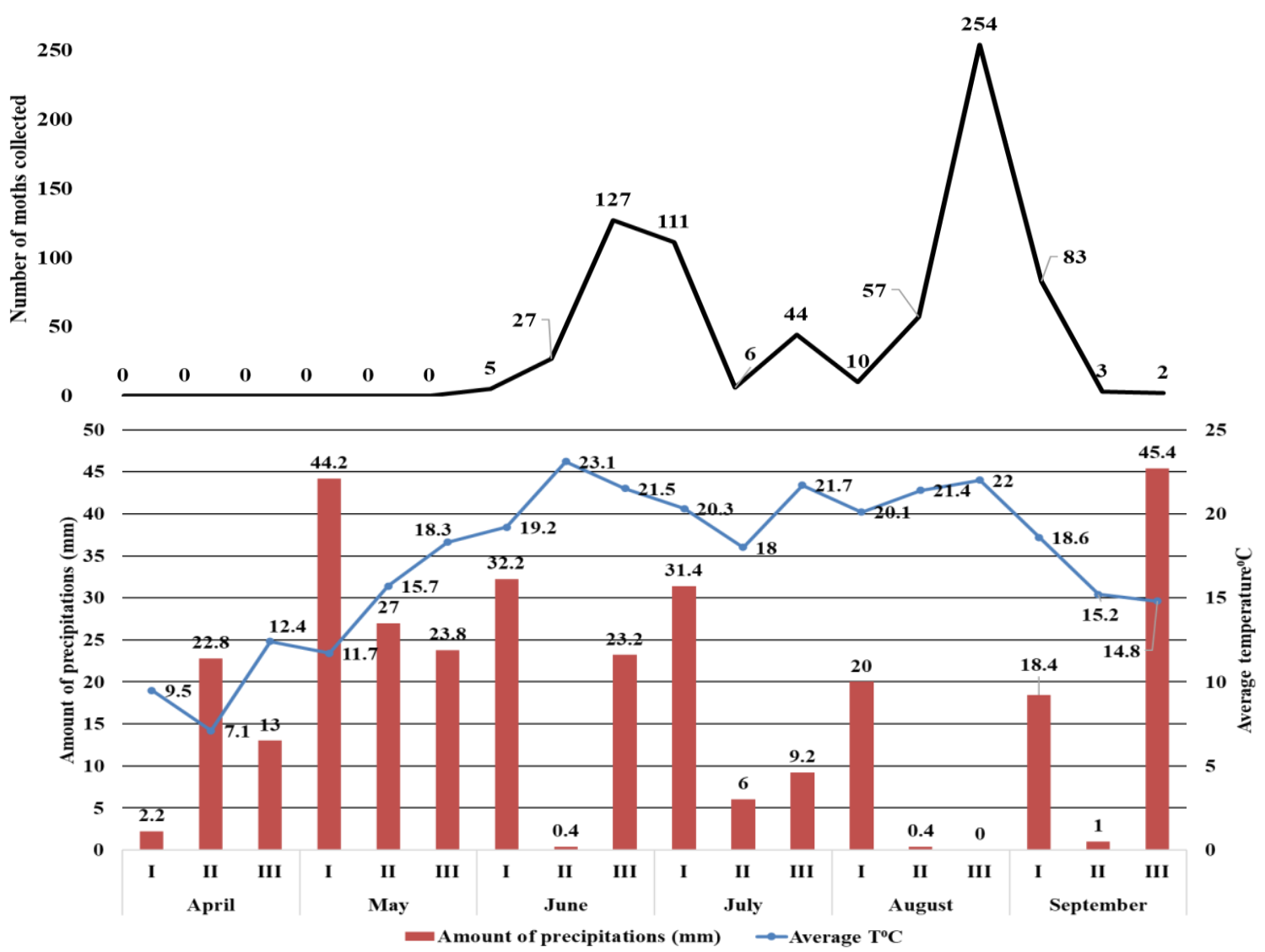

Figure 2. The Ostrinia nubilalis adult's flight curve in 2019 correlated with the climate conditions from April to September

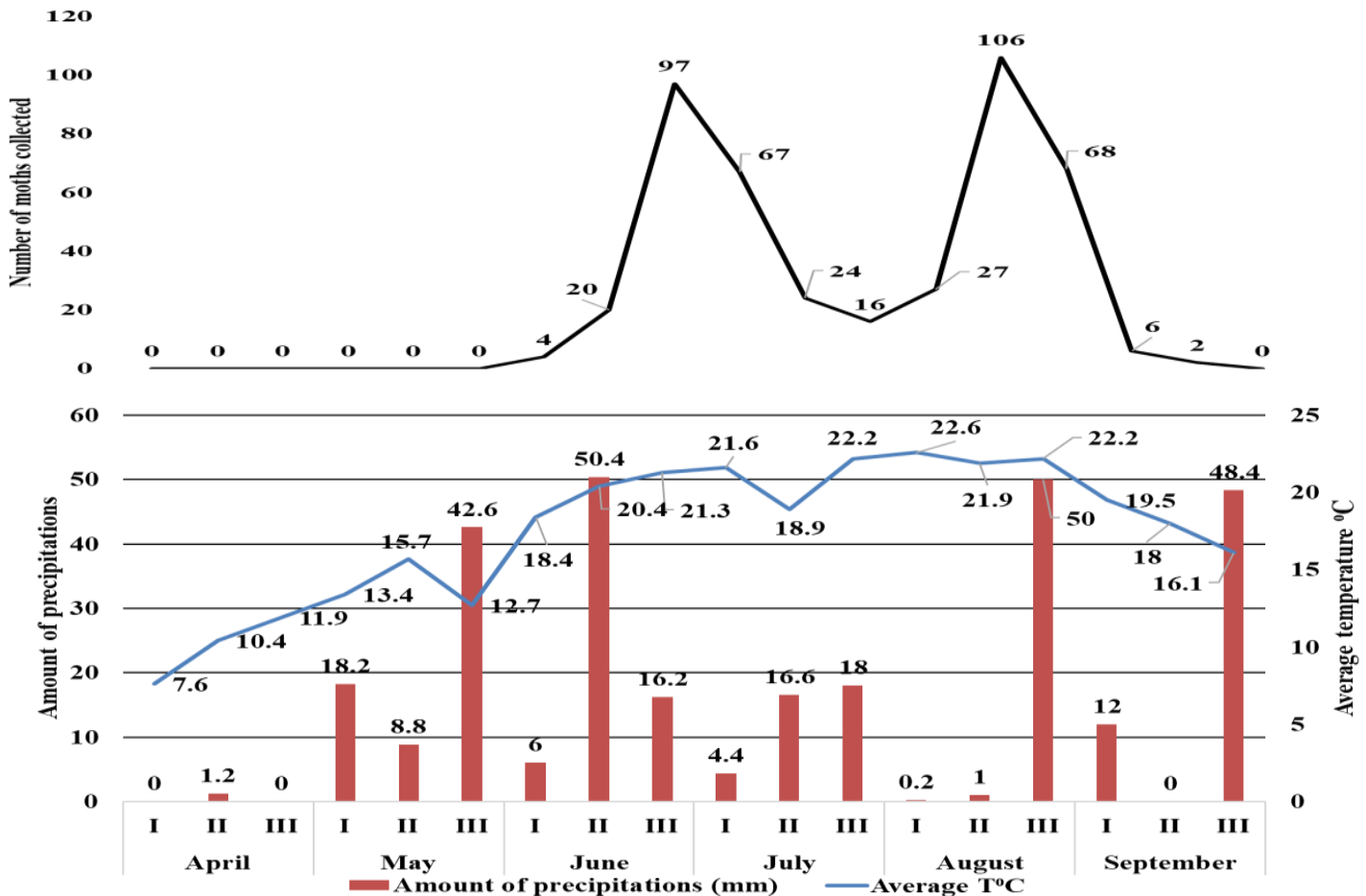

Figure 3. The Ostrinia nubilalis adults flight curve in 2020 correlated with the climate conditions from April to September 
Figures 1-3 show that between 2018 and 2020 the species $O$. nubilalis made flight curves, with maximum peaks at different times as follows:

- in 2018 there was an explosive appearance and an intense flight at the beginning June after which the flight decreases in intensity and continues, achieving a peak flight at the end of August;

- in 2019, the flight curve performed by the species $O$. nubilalis moths reached a peak at the end of June, a situation similar to that in 2020, after which the flight intensity is interrupted in both years in July by rainfall accompanied by hail (2020), the flight being intensified in August when it reaches a peak at the end of the month in 2019, respectively in mid-August in 2020.

The data presented show that the temperature and precipitation in May, June and July directly influence the intensity of species flight. The species overwinters in the mature larval stage inside the attacked organ, and in spring, the insect resumes its evolution by developing the larval stage and transforming into a pupa. The warming of the summer months, which were characterized in terms of temperature as normal (July) and warmer (June and August), respectively from dry to excessively dry in terms of rainfall, led to changes in the bio ecology of the species by the explosive appearance of moths in August, increasing flight intensities and peak flight in mid or at the end of the month.

According to Trotus et al. (2018), the flight of O. nubilalis adults in the period 1993 2017 started from mid-June and continued until the end of July, during this period being recorded the maximum flight peak, at the end of June or at the beginning of July. In the last years of observation 2018-2020, the flight of adults has undergone changes materialized by flight intensities in August and the achievement of peaks in mid or at the end of the month.

From the research carried out by Bărbulescu $(1996,1998,1999)$ it seems that in the south of the country a part of the larvae $(20 \%)$, those coming from the first hatchings turn into pupae, from which, at the end of August, butterflies appear, which marks the emergence of the second generation. The proportion of individuals that determine the appearance of the second generation of butterflies ranged from 5.4\% (1995) to 53\% (1998), being identified between 0.04 and 1.16 exuvial pupae / plant (Table 1).

Table 1. The proportion of occurrence of the second generation of the species Ostrinia nubilalis (according to Bărbulescu, 1996, 1998, 1999)

\begin{tabular}{|c|c|c|c|c|c|c|}
\hline \multirow{2}{*}{ No } & \multicolumn{2}{|c|}{1995} & \multicolumn{2}{c|}{1997} & \multicolumn{2}{c|}{1998} \\
\cline { 2 - 7 } & $\begin{array}{c}\text { Resistant } \\
\text { lines }\end{array}$ & $\begin{array}{c}\text { Sensitive } \\
\text { lines }\end{array}$ & $\begin{array}{c}\text { Resistant } \\
\text { lines }\end{array}$ & $\begin{array}{c}\text { Sensitive } \\
\text { lines }\end{array}$ & $\begin{array}{c}\text { Resistant } \\
\text { lines }\end{array}$ & $\begin{array}{c}\text { Sensitive } \\
\text { lines }\end{array}$ \\
\hline $\begin{array}{c}\text { Total exuvial } \\
\text { pupae / plant }\end{array}$ & 0.08 & 1.16 & 0.04 & 0.07 & - & - \\
\hline Butterflies \% & 5.4 & 12.35 & 8.6 & 11.6 & 12.34 & 53 \\
\hline
\end{tabular}

The large number of moths collected in present study in August each year would lead to the conclusion that $O$. nubilalis performs in the conditions of Central of Moldova, Romania, two flight peaks. However the existing data do not show that the insect has two generations per year, the realization of the second is in fact a continuation of the first peak, which, in all the years of observation, was diminished by the fallen precipitations.

\section{CONCLUSIONS}

The Ostrinia nubilalis moths collected between 2018 and 2020 totalled 1652 specimens, of which 488 moths in 2018, 729 moths in 2019 and 437 moths in 2020. 
The flight of moths started from mid-May in 2018, respectively in the first part of June in 2019 and 2020 and continued without interruption, until the end of September.

In the period 2018-2020, the flight curves of $O$. nubilalis recorded the maximum peaks at different times, influenced by temperature conditions and precipitation recorded in April to August.

The flight of moths has undergone changes, it was interrupted by rainfall in June and July, the flight increased in intensity in August in mid or the end of the month, when second peaks were recorded.

\section{REFRENCES}

BĂRBULESCU, Al. (1996). Rezultate obţinute în anul 1995 în cadrul cercetărilor privind bolile și dăunătorii cerealelor și unor plante tehnice și furajere. Probleme de protecția plantelor, 25, 2, 87-142.

BĂRBULESCU, Al. (1998). Rezultate obținute în anul 1997 în cadrul cercetărilor privind bolile și dăunătorii cerealelor și unor plante tehnice și furajere. Probleme de protecția plantelor, 26, 2,117-172. BĂRBULESCU, Al. (1999). Rezultate obținute în anul 1998 în cadrul cercetărilor privind bolile și dăunătorii cerealelor și unor plante tehnice și furajere. Probleme de protecția plantelor, 27, 2,157-162. DRĂGHICI, R. (2012). Results on the evaluation and limitation of attack produced by Ostrinia nubilalis Hbn. to maize cultivated on sandy soils. Analele Universităţii din Craiova. Seria Biologie, Horticultură, Tehnologia prelucrării produselor agricole, Ingineria mediului, 17, 53, 653-660.

GEORGESCU, E., CANĂ, L., IORDAN, H.L., MARTURA T., GĂRGĂRIŢĂ, R. (2013). The behavior of some maize hybrids at Ostrinia nubilalis $\mathrm{Hbn}$. attack under different climatic condition (Comportarea unor hibrizi de porumb la atacul de Ostrinia nubilalis Hbn. în condiţii climatice diferite). Analele INCDA Fundulea, 61, 113-139.

GROZEA, I., HORGOS, H., STEF, R., CARABET, A., VIRTEI, A. M., BUTNARIU, M., MOLNAR, L. (2019). Assessment of population density of insect species called "species problem", in lots with different maize hybrids, Research Journal of Agricultural Science, 51, 1, 132-137.

Ministerul Agriculturii si Dezvoltarii Rurale, Culturi de câmp, Cereale (Porumb), (2020). Available at www.madr.ro , https://www.madr.ro/culturi-de-camp/cereale/porumb.html [Accessed 17 nov. 2020].

POPOV, C., ROSCA, I. (2007).Technology of European Corn Borer (Ostrinia nubilalis Hbn.) mass rearing, in continuous system and successive generations. Entomological Research, 37, 1, 126.

TROTUŞ, E., BUBURUZ A.A., URSACHE P.L. (2017). Date noi privind protecţia culturilor de porumb împotriva dăunătorilor specifici, Volum omagial- 55 ani de cercetare dezvoltare, Ed. Ion Ionescu de la Brad, Iaşi, 115-130.

TROTUŞ, E., BUBURUZ A.A., URSACHE P.L (2018). New data regarding the appearance, evolution and the attack produced by Ostrinia nubilalis $\mathrm{Hbn}$. species, at maize crop, under the center of Moldavia conditions, Romanian Agricultural Research, 35, 229-236.

URECHEAN, V., BONEA, D. (2018). The comparative study of Bt corn and conventional corn regarding the Ostrinia nubilalis attack and the Fusarium spp. infestation in the central part of Oltenia, Romanian Biotechnological Letters, 23, 4, 13728-13735. 